PLANTS PEOPLE

POSSIBILITIES

\title{
Fungi Exotici: IX
}

\section{Author(s): G. Massee}

Source: Bulletin of Miscellaneous Information (Royal Botanic Gardens, Kew), Vol. 1909 , No. 5 (1909), pp. 204-209

Published by: Springer on behalf of Royal Botanic Gardens, Kew

Stable URL: http://www.jstor.org/stable/4113287

Accessed: 27-06-2016 05:06 UTC

Your use of the JSTOR archive indicates your acceptance of the Terms \& Conditions of Use, available at

http://about.jstor.org/terms

JSTOR is a not-for-profit service that helps scholars, researchers, and students discover, use, and build upon a wide range of content in a trusted digital archive. We use information technology and tools to increase productivity and facilitate new forms of scholarship. For more information about JSTOR, please contact support@jstor.org.

Royal Botanic Gardens, Kew, Springer are collaborating with JSTOR to digitize, preserve and extend access to Bulletin of Miscellaneous Information (Royal Botanic Gardens, Kew) 
"The colour of the sap-wood is white and that of the heart-wood a dull brown. The latter is rich in resin, and when burned gives off a fragrant odour resembling frankincense.

"The sap-wood, which in mature trees is a negligible quantity, is subject to attacks both by white ants and boring beetles, but the heart wood is impervious to all such insects. Owing to its great strength and durability this timber is invaluable for bridge and house piles and is generally employed locally for both these purposes. Although hard and heavy it can be readily sawn into planks which are admirably adapted for verandah floors, steps, and similar constructions which are constantly exposed to climatic influences."

XXIV.-FUNGI EXOTICI : IX.

\section{G. Massee.}

Until quite recently, in dealing with the general distribution of fungi, it was considered that the fleshy, perishable forms included in such genera as Boletus, Agaricus, Hydnum, \&c., were characteristic of, and mostly confined to, the north temperate zone, whereas dry, cartilaginous, or corky forms, represented by species of Polystictus, Hexagona, Stereum, \&c., were equally characteristic of tropical regions. We now know that this generalisation is incorrect, and was simply founded on the fact that the dry coriaceous species of fungi, requiring no attention in the way of drying, were collected by most botanists in the tropics; whereas the fleshy species, difficult to preserve under the most favourable of conditions, were systematically ignored.

The species of Boletus, being exceptionally fleshy and prone to decay, are practically unknown from tropical countries. The first African species, B. curtipes, Massee, was described in this Journal only last year. The present batch of species were all collected in the Botanic Gardens, Singapore, very beautifully coloured figures of each being made by Mr. C. G. de Alwis, and the specimens were preserved in spirit.

Twenty-two figures of species of Boletus were made from specimens collected in the gardens, and all these, judging from the figures, are well-marked, undescribed species. The condition of the spirit material in a few cases, however, did not enable a full diagnosis to be drawn up, but the fact of twenty species of Boletus occurring in such a limited area as that indicated proves that the most fleshy of fungi are well represented in tropical regions.

\section{Polyporacean.}

Boletus rufo-aureus, Massee.

Pileus globoso-pulvinatus, quandoque subumbonatus, carnosus, glaber, rufo-aureus, centrum versus fuscescens, margine involutus, levis, undulatus vel lobatus, $5 \mathrm{~cm}$. latus. Tubuli stipiti adnati, brevissimi, flavescentes ; pori minutissimi, rotundati, aureo-rufescentes. Stipes sursum incrassatus, solidus, pileo concolor, subsquamulosus vel maculis saturatioribus variegatus, basi pallidus, $7 \mathrm{~cm}$. 
longus, 2 cm. crassus. Sporae cylindrico-fusiformae, flavo-rubiginosae, $10 \times 4.5 \mu$. Caro compacta, albida, $1.5 \mathrm{~cm}$. crassa.

Singapore. On the ground, Ridley, 61, ser. 2.

A brilliantly coloured fungus, remarkable for the very short tubes (1-2 mm.) and the very minute, rounded pores. The pileus in some specimens has a suggestion of an umbo. Not closely allied to aìy published species, but showing affinity in some respects with Boletus spadiceus, Schaeffer.

Boletus altissimus, Massee.

Pileus conico-convexus, dein pulvinatus, glaber, aetate alveolatus, rufo-brunneus margine albido, $7-8 \mathrm{~cm}$. latus. Tubuli subliberi, elongati, flavo-virentes ; pori magni, polygoni vel flexuoso-oblongi, griseo-virides. Stipes solidus, aequalis, basi incurvatus, glaber, albobrunneus, $24-28 \mathrm{~cm}$. longus, $1 \mathrm{~cm}$. crassus ; annulus cortiniformis, superus. Sporae fusiformae, fuliginosae, 7-8 $\times 4 \mu$. Caro compacta, albida, $1 \mathrm{~cm}$. crassa, versus marginem tenuissima.

Singapore. On the ground, Ridley, 9, ser. 2.

A peculiar fungus, remarkable for the very long, equal, slender stem, bearing near the apex a cortinate ring or annulus. Not closely allied to any known species, but may be placed in the vicinity of Boletus bovinus, Fries.

Boletus bicolor, Massee.

Pileus pulvinatus, dein plus minusve depresso-undulatus, glaber, siccus, aurantiacus centro obscuriore, 5-6 cm. latus. Tubuli stipiti adnati vel subdecurrentes, albidi, $3-4 \mathrm{~mm}$. longi; pori elongatohexagoni, ampli, albidi. Stipes farctus, solidus, sursum incrassatus, glaber, pileo concolor, 4-5 cm. longus, sursum $1 \mathrm{~cm}$. crassus. Sporae fusiformae, albidae, flavo-tinctae, 7-8 $\times 4 \mu$. Caro spongiosa, albida, $1-1.5 \mathrm{~cm}$. crassa.

Singapore. On the ground, Ridley, 56, ser. 2.

Readily distinguished by the orange-coloured pileus and stem and the white pores. Allied to Boletus versipellis, Fries.

Boletus umbilicatus, Massee.

Pileus convexus, profunde umbilicatus, siccus, glaber, flavidoroseus, costis pallidis anastomosantibus eximie reticulatus, margine albidus, 4-6 cm. latus. Tubuli elongati, stipiti adnati vel subdecurrentes, flavo-virentes ; pori maximi, angulati, virescentes. Stipes solidus, sursum leviter incrassatus, longitudinaliter striatus, pileo concolor, 6-7 cm. longus, $1 \mathrm{~cm}$. crassus, subinde subflexuosus. Sporae fusiformae, viridi-flavescentes, 8-9 $\times 5 \mu$. Caro compacta, albida, $1.5 \mathrm{~cm}$. crassa.

Singapore. On the ground, Ridley, 78, ser. 2.

A very distinct and interesting species, remarkable alike for the deeply umbilicate pileus, a character unique in the genus, so far as at present known; the pileus ornamented with raised ribs, anastomosing to form an irregular network; and in the tufted habit of growth. Approaching Boletus caespitosus, Massee, in habit ; differing in the longer tubes and very large, angular pores.

Boletus Alwisii, Massee.

Pileus carnosus, compactus, pulvinatus, glaber, flavidus centro saturatiore, margine albido infractus, 3-4 cm. latus. Tubuli breves, 
stipiti adnati, flavescentes; pori parvi, subrotundi, flavidi, tactu virescentes. Stipes solidus, deorsum attenuatus, pileo concolor vel pallidior, supra annulum reticulatus, infra concentrice squamulosus, 5-6 cm. longus, $0.5 \mathrm{~cm}$. crassus. Sporae oblongo-fusoideae, subhyalinae, 6-7 $\times 4 \mu$. Caro albida, $0.5 \mathrm{~cm}$. crassa, versus marginem tenuissima.

Singapore. On the ground, Ridley, $42 \& 95$, ser. 2.

A very beautiful little Boletus, of a clear yellow colour throughout, belonging to the section including Boletus luteus, L., and B. flavus, With. The illustration indicates that $B$. Alwisii is gregarious in habit.

Boletus tristiculus, Massee.

Pileus convexo-explanatus, undulatus, siccus, pulverulentus, margine lobatus, griseo-lividus, 8-9 cm. latus. Tubuli concolores, elongati, circa stipitem profunde depressi; pori angulati, ampli, griseo-rufescentes. Stipes solidus, elongatus, sursum attenuatus, supra annulum obsoletum pallidus, reticulatusque, infra subsquamulosus squamulis compressis, $8-9 \mathrm{~cm}$. longus, $2-3 \mathrm{~cm}$. crassus. Sporae fusiformae, pallidae, $8-9 \times 4.5 \mu$. Caro compacta, albida, fracta subcinerascens, $1 \cdot j \mathrm{~cm}$. crassa.

Singapore. On the ground, Ridley, 80, ser. 2.

A somewhat dingy-looking fungus, the prevailing colour being a livid grey. Allied in structure to Boletus chrysenteron, Fries.

Boletus albellus, Massee.

Pileus pulvinatus, carnosus, expanso-depressus vel undulatus, siccus, glaber, albus, 8-10 cm. latus. Tubuli albido-flavi, liberi; pori concolores, angulati vel sinuato-oblongi, ampli. Stipes farctus, subaequalis vel leviter basi incrassatus, concolor, undique reticulatus, maculis flavescentibus variegatus, $8-9 \mathrm{~cm}$. Iongus, $2-3 \mathrm{~cm}$. crassus. Sporae fusiformae, pallide flavo-virides, uniguttulatae, 10-12 × 6-7 $\mu$. Caro albida, fracta sublutea, $1.5 \mathrm{~cm}$. crassa.

SINGAPore. On the ground, Ridley, 11, ser. 2.

A very distinct species, characterised by the pileus becoming more or less depressed and undulated with age, the white colour of every part, a tinge of yellow only appearing in the tubes and on the stem, and more especially by the sub-equal stem being everywhere covered with raised ribs, anastomosing to form an irregular network. Allied to the group of species of which B. chrysenteron, Fries, may be accepted as typical.

Boletus pachycephalus, Massee.

Pileus pulvinatus, velutinus, brunneus centro saturatiore, $5 \mathrm{~cm}$. diam. Tubuli brevissimi, stipiti adnati vel decurrentes, ex albo sublutescentes; pori angulati aut sinuoso-elongati, mediocres, roseo-rufescentes. Stipes solidus, curtus, basi incrassatus, nigrobrunneus, glaber, 2-3 cm. longus, $1.5 \mathrm{~cm}$. crassus. Sporae ellipsoideae, flavo-virides, $8-9 \times 4 \mu$. Caro alba, immutabilis, crassissima, compacta.

Singapore. On the ground, Ridley, 24, ser. 2.

Remarkable for the very dark colour of the stem and pileus, very short tubes, and exceedingly thick, compact, unchangeable tlesh. Allied to B. chrysenteron, Fr. 
Boletus funerarius, Massee.

Pileus carnosus, e subhemispherico expansus depressusve, subumbonatus, siccus, velutinus, atro-brunneus, interdum centro squamulosus, 8-10 cm. latus. Tubuli stipiti adnati, elongati, fuscescentes ; pori magni, elongato-hexagoni, brunnei. Stipes farctus, aequalis, longitudinaliter fibroso-striatus, brunneus, $5-6 \mathrm{~cm}$. longus, $1-\overline{\mathrm{cm}}$. crassus. Sporae fusiformae, leniter curvatae, olivaceo-griseae, 9-10 × 4-4.5 $\mu$. Caro compacta, alba, $2 \mathrm{~cm}$. crassa.

Singapore. On the ground, Ridley, 50, ser. 2.

A sombre, uninviting species, characterised by brownish-black veivety pileus and brown tubes and pores. The general structure approaches that of Boletus chrysenteron, Fries.

Boletus Ridleyi, Massee.

Pileus pulvinatus, velutinus, hinc inde lacunosus vel quasi alveolatus, laete incarnatus, siccus, $8-9 \mathrm{~cm}$. latus. Tubuli elongati, adnati, flavo-virentes : pori angulati vel elongato-hexagoni, tubuli concolores. Stipes farctus, peraltus, sursum attenuatus, alveolatus alveolis elongatis, pileo concolor, sursum flavicans, $12-15 \mathrm{~cm}$. longus, ad basin $3 \mathrm{~cm}$. crassus. Sporae fusoideae, olivaceo-tingentes, 12-13 $\times 5 \mu$. Caro albida, spongiosa vel cavernosa, fracta subrubescens.

Singapore. On the ground, Ridley, 87, ser. 2.

$A$ very beautiful and distinct species, characterised by the clear flesh-coloured, velvety pileus, and the very long, alveolate, red stem. Allied to B. subtomentosus, L., and B. impolitus, Fries.

Boletus unicolor, Massee.

Pileus pulvinatus, levis, glaber, ochraceus centro fuscidulo, margine primo involuto dein fisso, 9-10 cm. latus. Tubuli ochraceovirentes, adnati vel subdecurrentes ; pori angulati ampli, ochraceorufescentes. Stipes solidus, elatus, deorsum attenuatus, fibrosostriatus, pileo concolor, 10-12 cm. longus, sursum $2.5 \mathrm{~cm}$. crassus. Sporae pallide ochraceae, oblongo-ellipticae, 11-12 5 . . Caro persistenter alba, crassa, compacta.

Singapore. On the ground, Ridley, 99, ser. 2.

Readily distinguished by the ochraceous colour of every part, the elongated, fibrillosely striated stem, tapering downwards. Belongs to the section of the genus including Boletus bovinus, Fries.

\section{Boletus longipes, Massee.}

Pileus convexo-planus, in exoletis centro plus minusve depressus, viscosus, glaber, griseus centro saturatiori, 3-4 cm. latus. Tubuli elongati, flavo-virentes, liberi ; pori angulati, ampli, griseo-flavidi, marginibus flavi. Stipes solidus, elongatus, subaequalis vel basi subincrassatus, flexuosus, glaber, pileo concolor, basi albus, 7-8 cm. longus, 2-3 mm. crassus. Sporae flavo-brunneae, ellipsoideae, leniter curvatae, $12 \times 5 \mu$. Caro alba.

SingaPore. On the ground, Ridley, 81, ser. 2.

Remarkable for the long, slender, flexuous stem. The pileus is plane, becoming depressed at the centre when old. This species is probably gregarious, as nine excellently preserved specimens accompanied the coloured drawing. Approaching $B$. fuligineus, Fries, in general structure. 
Boletus parvulus, Massee.

Pileus hemisphaerico-explanatus, obtusissime umbonatus, margine integro undulato, minute squamulosus, pulchre flavo-fulvescens centro obscuriore, 5-6 cm. latus. Tubuli in stipite subdecurrentes, curti, cinerascentes ; pori minutissimi, rotundati, roseo-tincti. Stipes solidus, sursum incrassatus, glaber, pileo concolor, 4-5 cm. longus, supra 1-5 cm. crassus. Sporae cymbiformae, vix carneo-tinctae, 7-8 $\times 5 \mu$. Caro spongiosa, $1.5 \mathrm{~cm}$. crassa, albida.

Singapore. On the ground, Ridley, 56 bis, ser. 2.

A very neat, clear-coloured fungus, characterised by the tawnyyellow pileus and stem, and the rose-tinted pores.

Allied in general structure to Boletus rufo-aureus, Massee ; differing in the smaller size, minutely squamulose pileus and rosy pores.

Boletus nanus, Massee.

Pileus pulvinatus, carnosus, interdum undulatus, siccus, primitus levis dein centro rimoso-areolatus, olivaceo-fuscus, $1-1 \cdot 5 \mathrm{~cm}$. latus. Tubuli subliberi, curti, flavescentes; pori angulosi, pro ratione magni, flavo-virentes. Stipes solidus, plus vel minus flexuosus, æqualis, luteus apice roseus furfuraceusque, $4 \mathrm{~cm}$. longus, $3-4 \mathrm{~mm}$. crassus. Sporae fusoideae, flavido-albae, $6 \times 3.5 \mu$. Caro compacta, albida, versus marginem tenuissima.

Singapore. On the ground, gregarious, Ridley, 39, ser. 2.

A very beautiful and well-marked species, reproducing in miniature all the characteristic features of Boletus chrysenteron, Fries.

Boletus flexipes, Massee.

Pileus tenuis, e convexo planus, interdum centro depressus, glaber, castaneus, zona lata umbrina in medio pilei ornatus, 4-5 cm. latus. Tubuli in stipite subdecurrentes, curti, flavescentes ; pori rotundati, minutissimi, aurei. Stipes solidus, flexuosus, sursum attenuatus, pallidus vel tinctura leviter rubescente-flavida praeditus, $6 \mathrm{~cm}$. longus, 6-8 mm. latus. Sporae oblongo-fusoideae, interdum curvulae, 7-9 × 5 . Caro 3-4 mm. crassa, compacta.

Singapore. On the ground, Ridley, 97, ser. 2.

A very beautiful species, readily recognised by the plane, chestnut-coloured pileus, golden pores, and pallid, flexuous stem. Its affinity is with Boletus vaccinus, Fries.

Boletus flavipes, Massee.

Poleus primo hemisphaericus, dein modice explanatus, margine non vel vix curvulus, dein gradatim expansus, laevis, glaber, sordide castaneus, 3-4 cm. latus. Tubuli stipiti adnati, curti ; pori rotundati, minuti, albi. Stipes teres, subflexuosus, farctus, aetate cavus, flavus, $4 \mathrm{~cm}$. longus, 5-6 mm. crassus. Sporae fusiformae, subhyalinae, 6-7 $\times 3.5 \mu$. Caro compacta, 1 cm. crassa, albida.

Singapore. On the ground, Ridley, 25, ser. 2.

A very neat little species, characterised by the white tubes and pores and the slightly flexuous, yellow stem. Allied to Boletus tenuipes, Cooke. 
Strobilomyces paradoxus, Massee.

Pileus carnosulus, margine abrupte tenuis, incurvus, primo hemisphaericus, dein explanatus, umbrinus, dense irregulariterque verrucosus, aetate glabrescens, 6-7 cm. latus. Tubuli curtissimi, stipiti adnati ; pori polygoni seu alveolati, brunnei. Stipes farctus, subaequalis, glaber, pileo concolor, 4-5 cm. longus, 5-6 mm. crassus. Sporae oblongo-ovatae, basi oblique apiculatae, longitudinaliter striatae, flavo-brunneae, $9-11 \times 5 \mu$.

SingaPORE. Un the ground, gregarious, Ridley, 28, ser. 2.

A very remarkable speries, possessing features characteristic of the genera Boletus and Strobilomyces respectively. It approaches the last-named genus in the characteristic dusky brown colour; warted pileus becoming glabrous when old ; oblong form of spores, with an ornamented epispore. On the other hand, all previously known species of Strobilomyces have a very fleshy pileus, shaggy stem, and long tubes. The points in common with Boletus are smooth stem, short tubes, as in B. flexipes, Mass., and thin flesh, as in $B$. bovinus, $\mathrm{L}$.

\section{XXV.-MYROBALANS. (Terminalia Chebula, Retz.)}

The following article on this important tanning material of commerce, to which some additional information is added, appeared in the Indian Forester, 1907, p. 362 :-

"On the Western Ghauts this species does not usually exceed a height of 25 feet or a girth of $3 \frac{1}{2}$ feet. The bole as a rule is very short, branching often beginning lower than 2 feet from the ground. The crown is very spreading and the root system shallow. The species is essentially light-demanding. It flourishes on laterite at an altitude of 4,500 feet ; here its chief associate is Eugenia Jambolana. The new foliage appears about the beginning of April, soon after which the flowers, all bisexual, are displayed in spikes ; on an average there are about 40 flowers in each inflorescence, but the number of ovaries ultimately developing into fruit on a single peduncle does not usually exceed 10. The leaves are mostly subopposite, glabrous, shining and coriaceous, measuring 3-6 in. by 2-2 in.

"The fruit (the Myrabolam of Commerce), which is a drupe ovoid in shape and an inch long b.y half an inch broad in the middle, is also glabrous and appears about the end of May. It is at this time light green with tiny yellow spots ; the upper part, perhaps on account of the influence of stronger light, frequently changes to a dark purple maroon.

"During the monsoon the fruit turns a greenish yellow. At this period the 'hirda' (this is the name by which the fruit is known to the Maharatta) is sold by auction whilst on the tree, and materially adds to the revenues of those Forest Divisions situated in the T. Chebula zone.

"The successful bidder begins collecting in October, and for his convenience depôts are erected at suitable centres, serving also the 